\title{
Respirometric analysis of Penicillium simplicissimum growth in solid-state fermentation using Jatropha cake as culture medium
}

\author{
Mateus Godoy ${ }^{1 *}$, Sevastianos Roussos ${ }^{2}$, Denise Freire \\ From 5th Congress of the Brazilian Biotechnology Society (SBBIOTEC) \\ Florianópolis, Brazil. 10-14 November 2013
}

Jatropha cake (JC), a toxic residue derived from the extraction of the oil from Jatropha curcas seeds, can be used as a culture medium for solid-state fermentation (SSF). Through this process, it is possible to detoxify and add value to this solid residue through the production of enzymes of biotechnological interest. However, one of the major technological bottlenecks in SSF is the microbial growth control. This study aims to monitor the growth of the fungus $P$. simplicissimum in JC by respirometry and compare this process of lipase production in traytype bioreactor with the one in Raimbault columns.

First, the experiments were carried out and optimized in tray-type bioreactors. After two sequential experimental designs - Plackett-Burman and Central Composite Rotatable Design - a production of $140 \mathrm{U} / \mathrm{g}$ was reached, representing a 9-fold increase of the initially obtained activity.

Based on the conditions indicated by the experimental design, the fermentations were carried out on Raimbault columns [1]. In these experiments, it was possible to follow the profile of $\mathrm{CO}_{2}$ production by $P$. simplicissimum through respirometric analysis. It was observed a high and fast production of $\mathrm{CO}_{2}$ over the first $24 \mathrm{~h}$ of growth. After this time, there is a reduction of the $\mathrm{CO}_{2}$ release and the fungus achieve its basal metabolism around $96 \mathrm{~h}$. In spite of the intense fungal growth, a low lipase production was reached $(50 \mathrm{U} / \mathrm{g})$, in contrast with the one obtained in tray-type bioreactors. This behavior is probably due to the strong compression of the solid culture medium and, consequently, the difficulty of heat and mass transfer, even under forced aeration. In order to reduce the compaction of the medium, a mixture of JC

\footnotetext{
'Universidade Federal do Rio de Janeiro, Laboratório de Biotecnologia Microbiana, Departamento de Bioquímica, Instituto de Química, 21941-909, Rio de Janeiro, RJ, Brazil

Full list of author information is available at the end of the article
}

with sugarcane bagasse was used. Sugarcane bagasse (SCB) is widely used in SSF with other agroindustrial residue for better "structure" the culture medium, avoiding compaction problems [2]. After some assays, a medium composed of $15 \%(\mathrm{~m} / \mathrm{m})$ of SCB and $85 \%(\mathrm{~m} / \mathrm{m})$ of JC was used. After sugarcane bagasse addition, the lipase production was $160 \mathrm{U} / \mathrm{g}$, near to the one obtained in tray-type bioreactor.

The production profile of $\mathrm{CO}_{2}$ is similar to those obtained by other fungi cultivated in SSF and in other culture mediums [3]. However, in both curves obtained, an unusual small change in the stage of metabolism in the first $24 \mathrm{~h}$ was observed in all experiments, probably due to the waste toxicity. The phorbol ester content (the major toxic component) was $70 \%$ reduced reaching a final concentration of $676 \mu \mathrm{g} / \mathrm{g}$.

From these experiments, it is observed that (i) for SSF in columns bioreactors with JC, the use of sugarcane bagasse (or other inert raw material) to structure the culture medium is essential, avoiding compaction, (ii) the fungus $P$. simplicissimum reached a high lipase production when grown in Raimbault columns with JC and $\mathrm{SCB}$, reaching a production of $160 \mathrm{U} / \mathrm{g}$, (iii) through the respirometric system to monitoring the fungal growth, it is possible to see the stages of metabolism change of the fungus, allowing further studies and (iv) the fungus was able to reduce $70 \%$ of the phorbol esters content after 26h of fermentation.

\footnotetext{
Authors' details

${ }^{1}$ Universidade Federal do Rio de Janeiro, Laboratório de Biotecnologia Microbiana, Departamento de Bioquímica, Instituto de Química, 21941-909, Rio de Janeiro, RJ, Brazil. ${ }^{2}$ Aix-Marseille Université (AMU), Institut Mediterranéen de Biodiversité et d'Ecologie Marine et continentale (IMBE), Équipe de Biotechnologies et Bioremédiation (B\&B), 13397, Marseille, France.
} 


\section{References}

1. Raimbault M, Alazard D: Culture method to study fungal growth in solid fermentation. Eur J Appl Microbiol 1980, 9:199-209.

2. Raimbault M: General and microbiological aspects of solid substrate fermentation. Electron J Biotechnol 1998, 1(3).

3. Saucedo-Castaneda G, Trejo Hernandez Mr, Lonsane Bk, Navarro Jm, Roussos S, Dufour D, Raimbault M: On-line automated monitoring and control systems for $\mathrm{CO} 2$ and $\mathrm{O} 2$ in aerobic and anaerobic solid-state fermentations. Process Biochem 1994, 29:13-24.

doi:10.1186/1753-6561-8-S4-P220

Cite this article as: Godoy et al:: Respirometric analysis of Penicillium simplicissimum growth in solid-state fermentation using Jatropha cake as culture medium. BMC Proceedings 2014 8(Suppl 4):P220.

\section{Submit your next manuscript to BioMed Central} and take full advantage of:

- Convenient online submission

- Thorough peer review

- No space constraints or color figure charges

- Immediate publication on acceptance

- Inclusion in PubMed, CAS, Scopus and Google Scholar

- Research which is freely available for redistribution

Submit your manuscript at www.biomedcentral.com/submit
C Biomed Central 